\title{
PENGEMBANGAN SISTEM KONTROL DAN PEMANTAUAN TETESAN CAIRAN INFUS OTOMATIS BERBASIS LABVIEW DENGAN LOGIKA FUZZY
}

\author{
Riky Tri Yunardi' ${ }^{1}$, Dani Setiawan², Farah Maulina ${ }^{3}$, Tri Anggono Prijo ${ }^{4}$ \\ ${ }^{1,2,3}$ Departemen Teknik, Fakultas Vokasi, Universitas Airlangga \\ ${ }^{4}$ Departemen Fisika, Fakultas Sains dan Teknologi, Universitas Airlangga \\ Email: ${ }^{1}$ rikytriyunardi@vokasi.unair.ac.id
}

(Naskah masuk: 10 April 2018, diterima untuk diterbitkan: 05 September 2018)

\begin{abstract}
Abstrak
Dalam instrumentasi medis infus merupakan perangkat yang digunakan untuk mengalirkan cairan, obat atau nutrisi secara intravena. Fungsi utama dari infus yaitu memberikan cairan secara periodik pada pasien. Perangkat infus saat ini, untuk mengendalikan kecepatan tetesan cairan dilakukan secara manual oleh staf medis. Permasalahan yang sering sering ditemukan, seperti penyumbatan dan habisnya cairan infus yang apabila tidak cepat diatasi akan berbahaya bagi pasien. Penelitian ini bertujuan untuk mengembangkan prototipe sistem kontrol dan pemantauan aliran cairan infus secara otomatis. Dengan menggunakan LabVIEW National Instruments untuk memantau tetesan cairan infus. Sistem kontrol logika Fuzzy diimplementasikan dengan menggunakan mikrokontroler berbasis ATmega, yang dilengkapi dengan pompa udara, motor stepper dan pendeteksi aliran cairan. Kinerja dari sistem prototipe pemantauan aliran cairan infus secara otomatis memiliki tingkat keberhasilan $96,75 \%$ dengan nilai set point 20 tetes dalam waktu 1 menit.
\end{abstract}

Kata kunci: infus, kecepatan tetesan cairan, LabVIEW, logika fuzzy

\section{CONTROL SYSTEM DEVELOPMENT AND MONITORING OF AUTOMATIC LIQUID DROPLETS INFUSION BASED ON LABVIEW WITH FUZZY LOGIC}

\begin{abstract}
In the medical instrumentation infusion is a device used to drain fluids, medication or nutrients intravenously. The main function of the infusion is to give fluids periodically in patients. Infusion device at this time, to control the speed of the liquid droplets is done manually by the medical staff. Problems often occur, such as a blockage or run out of the fluid content and if not promptly treated can be harmful to the patient. This research aims to develop a prototype of control system and monitoring of the infusion liquid droplets automatically. By using the National Instruments LabVIEW to monitor the flow of intravenous fluids. The Fuzzy logic control system is implemented using an ATmega based microcontroller, equipped with air pumps, stepper motors and liquid flow detection. The performance of the prototype system of monitoring the flow of intravenous fluids automatically have a success rate of $96.75 \%$ at the set point value of 20 drops in 1 minute.
\end{abstract}

Keywords: infusion, fluid droplets rate; LabVIEW, fuzzy logic

\section{PENDAHULUAN}

Dengan perkembangan teknologi yang semakin canggih dan modern saat ini kebutuhan peralatan kesehatan yang lebih praktis dan mudah sangat dibutuhkan. Demikian juga dengan perkembangan teknologi instrumentasi medis sebagai penunjang kebutuhan peralatan medis yang digunakan untuk melayani pasien. Salah satunya yaitu infus, yaitu alat medis yang digunakan pada kondisi tertentu untuk memberikan cairan ke dalam tubuh pasien secara periodik. Cairan, obat atau nutrisi yang dimasukkan menggunakan infus langsung melalui pembuluh darah (vena) secara intravena (Wadianto, dkk., 2016). Untuk mengetahui kecepatan aliran cairan yang masuk ke dalam tubuh, dapat diamati pada jumlah tetasan pada chamber infus. Pada kenyataannya, infus masih digunakan secara manual oleh petugas medis untuk mengatur dan menghitung jumlah tetesan cairan yang diberikan kepada pasien (N. Muljodipo, dkk., 2015).

Dengan keterbataan kemampuan petugas medis juga dapat melakukan kesalahan dalam pemberian cairan infus menjadi suatu hal yang mungkin saja terjadi. Kesalahan dalam pemasangan infus yang sering terjadi, seperti penyumbatan atau kehabisan isi cairan tanpa diketahui oleh tenaga medis dan apabila tidak segera ditangani dapat berbahaya bagi pasien. Hal ini dapat mengakibatkan tekanan darah pasien 
pada selang infus tidak akan astabil dan dapat tersumbat karena pembekuan darah (A. Zainuri, dkk., 2012). Hal ini menunjukkan bahwa proses pemasangan dan pemantauan infus harus dilakukan dengan cara yang benar untuk mengurangi bahaya tersebut.

Pada penelitian sebelumnya (R.A. Primahayu, dkk., 2017) membahas desain sistem monitoring cairan infus untuk memantau kondisi cairan didalam tabung infus menggunakan pengolahan citra digital. Untuk memisahkan citra objek berupa cairan dengan latar belakang menggunakan metode thresholding. Luas area piksel pada gambar mendiskripsikan bentuk dan kondisi cairan infus. Dengan menggunakan sensor kamera maka kondisi cahaya lingkungan akan sangat berpengaruh terhadap hasil capture. Pada sistem ini hanya mendeteksi cairan infus dan belum mampu mendeteksi jumlah tetesan cairan infus.

Wadianto (Wadianto, dkk., 2016) telah membuat sebuah alat yang digunakan untuk mengumpulkan informasi jumlah tetesan cairan infus pada drip chamber. Untuk mendeteksi tetesan cairan menggunakan sensor optocoupler yang berbasis cahaya. Sebagai tambahan sistem ini dilengkapi dengan indikator untuk mengetahui kondisi cairan di dalam tabung. Dari hasil perancangan yang telah dibuat memiliki nilai keakurasian yang cukup baik.

Sistem monitoring infus berbasis mikrokontroler untuk membantu pasien rawat inap di rumah sakit juga telah dirancang (Nataliana, 2016). Namun agar sistem ini dapat bekerja dengan fungsinya maka peletakan tabung infus haruss dipertimbangkan. Tabung infus harus diletakkan pada ketinggian $170 \mathrm{~cm}$ dari permukaan lantai, sehingga membutuhkan sebuah tiang sebagai penompang, dari sistem yang telah dibuat belum menerapkan kecerdasan buatan.

Sebuah sistem monitoring cairan intravena telah dirancang dengan tujuan untuk memberikan informasi kepada tenaga medis status keadaan cairan infus di dalam tabung (Riskitasari, S., dkk, 2016). Metode yang digunakan dengan memanfaatkan sensor load cell untuk mengukur massa cairan yang dikonversi besarannya menjadi volume cairan. Dan hasilnya dikirim ke server melalui perangkat nirkabel Zigbee namun belum memiliki sistem nonitoring dan gambar grafik secara real time.

Berdasarkan latar belakang tersebut maka dalam penelitian ini dirancang sebuah sistem kontrol dan pemantauan tetesan cairan infus otomatis. LabVIEW digunakan untuk membuat tampilan layar komputer graphic user interface yang digunakan untuk memantau tetesan cairan infus secara real time dan mengiplementasikan sistem kontrol logika Fuzzy untuk mengambil keputusan berdasarkan nilai kecepatan tetesan cairan menggunakan mikrokontroler berbasis Arduino.

\section{METODE PENELITIAN}

\subsection{Infus}

Infus merupakan suatu prosedur memasukkan cairan dalam jumlah tertentu melalui jalur intravena yang diterapkan pada pasien pada kondisi tertentu untuk memberikan cairan atau elektrolit sebagai prosedur tindakan dalam pengobatan. Terapi penggunaan infus intravena membutuhkan penanganan oleh dokter dan pengawasan oleh tenaga medis dalam memantau kecepatan tetesan cairan infus untuk mencegah risiko terhadap pasien.

Tetesan Per menit $=\frac{\text { Volume Cairan }(m L) \times 20}{\text { Waktu }(\text { detik }) \times 60}$

Untuk menghitung kecepatan aliran dalam bentuk tetesan dihitung setelah mengetahui jumlah volume cairan yang tekumpul dalam satuan waktu berdasarkan umur orang dewasa (makro dengan 20 tetes/ml) seperti pada Persamaan (1).

\subsection{Program LabVIEW}

Program LabVIEW merupakan suatu bahasa pemrograman komputer dengan basis grafis dengan menggunakan diagram blok sebagai bentuk lain selain dari teks untuk membuat aplikasi komputer. Pemrograman menggunakan blok dalam bentuk dataflow, yang menentukan alur eksekusi dari program yang telah dibuat. Tampilan pada LabVIEW menghasilkan tampilan sebuah panel layar instrument secara virtual.

\subsection{Logika Fuzzy}

Logika fuzzy termasuk dalam sistem kontrol yang menerapkan kecerdasan buatan yang memiliki kemampuan untuk menyesuaikan masalah oleh sebuah plan (Yunardi, R.T., dkk., 2017). Sistem kendali fuzzy terdiri dari beberapa tahap yaitu fuzzyfication, inference dan defuzzyfication. Fuzzifikasi merupakan proses konversi variabel crisp menjadi variabel fuzzy guna memperoleh derajat keanggotaan pada tiap masukkan. Inference digunakan untuk menetukan nilai derajat keanggotaan dari keluaran fuzzy. Hubungan antara masukkan dan keluaran menggunakan aturan if-then yang diterapkan pada perangkat kendali mikrokontroler.

Tahap defuzzifikasi digunakan untuk mendapatkan nilai derajat keanggotaan dengan mengkonversi variabel fuzzy menjadi variabel crisp berupa nilai numerik. Proses defuzzifikasi pada perancangan sistem kendali menggunakan model Sugeno dengan posisi singelton pada sumbu $\mathrm{Z}$ seperti yang ditunjukkan pada Persamaan (2). 
$Z_{\text {Output }}=\frac{\sum \mu(Z) Z d z}{\sum \mu(Z) d z}$

\subsection{Metodologi}

Cara kerja dari pengembangan prototipe sistem infus otomatis pada dapat dijelaskan seperti pada gambar diagram blok pada Gambar 1. Sistem kerja dimulai dengan memberikan nilai masukkan berupa laju tetesan cairan infus. Sensor optocoupler mendeteksi adanya tetesan yang ada di dalam drip chamber, kemudian sinya dari sensor dikondisikan oleh rangkaian pengkondisi sinyal (Setiawan. D. dan Maulina, F., 2017).

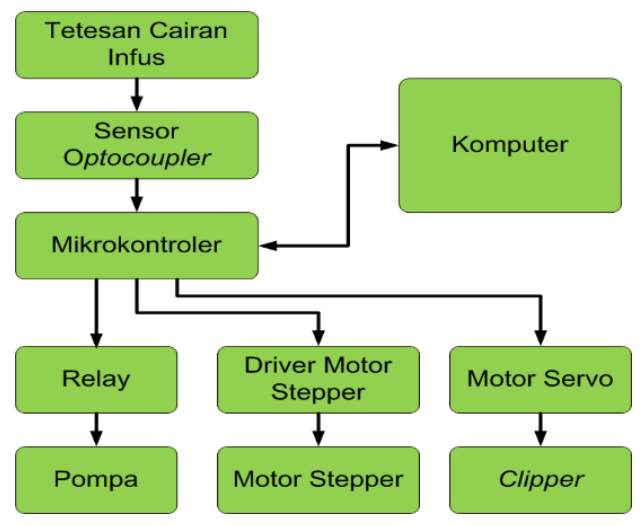

Gambar 1. Diagram blok cara kerja prototipe sistem infus otomatis
Mikrokontroler digunakan untuk mengolah data dan sebagai perangkat sistem kendali serta menerima dan mengirimkan data dengan komputer menggunakan data serial. Mikrokontroler mengaktifkan relay untuk mengendalikan pompa yang berfungsi untuk mengalirkan udara tekan pada tabung infus jika kecepatan tetesan cairan infus kurang dari nilai set point tetesan yang telah ditentukan. Dalam perancangan ini, manset digunakan sebagai alat penekan permukaan tabung infus. Motor stepper digunakan untuk menekan selang pompa apabila mesin pompa dalam keadaan tidak aktif untuk mencegah udara tekan tidak keluar dari manset. Sebagai sistem pengaman aliran antara tabung infus dengan pembuluh darah (vena) maka motor servo digunakan untuk menggerakkan clipper pada selang infus. Clipper berfungsi untuk menjepit dan membuka aliran selang infus.

\section{PERANCANGAN SISTEM}

\subsection{Perancangan Elektrik Sistem Infus Otomatis}

Pada perancangan skema elektrik terdiri dari beberapa komponen yang digunakan antara lain rangkaian power supply, rangkaian sensor optocoupler, minimum system mikrokontroler, driver motor stepper, relay, dan buzzer seperti yang telah ditunjukkan pada Gambar 2.

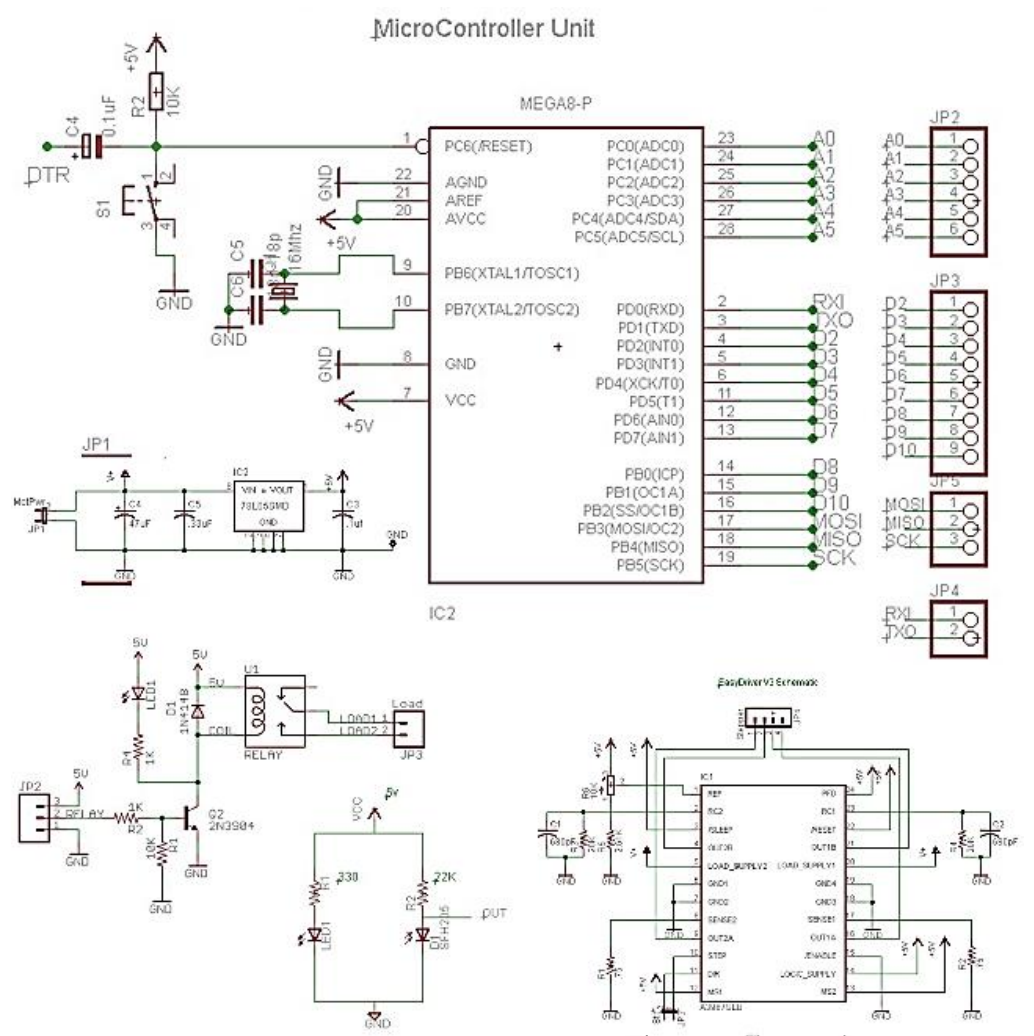

Gambar 2. Perancangan skema elektrik sistem infus otomatis 


\subsection{Perancangan Rangkaian Sensor Tetesan Cairan Infus Menggunakan Optocoupler}

Pada perancangan rangkaian tetesan cairan infus menggunakan optocoupler dengan menggunakan cahaya sebagai pendeteksi. Sumber cahaya sebagai transmitter dan photo-detector sebagai receiver. Sensor mendeteksi jumlah tetesan setiap satu menit. Sensor mengirim sinyal tegangan sebagai masukkan mikrokontroler untuk mendapat jumlah tetesan. Jumlah set point tetesan digunakan sebagai pembanding dari jumlah yang terhitung. Dan apabila sesuai dengan set point maka sistem infus otomatis untuk mempertahankan jumlah tetesan sebesar set point. Rangkaian sensor tetesan cairan infus menggunakan photo-detector pada drip chamber ditunjukkan pada Gambar 3.

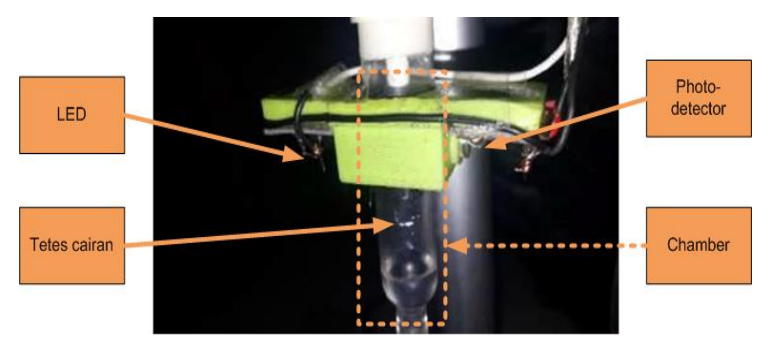

Gambar 3. Sensor tetesan cairan infus menggunakan optocoupler pada drip chamber

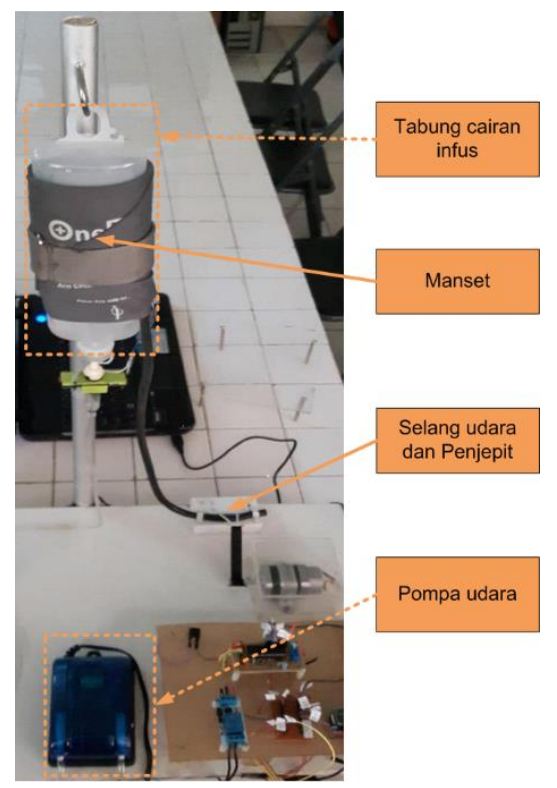

Gambar 4. Mekanik penekan tabung cairan infus

\subsection{Perancangan Mekanik Penekan Permukaan Tabung Cairan Infus}

Dalam perancangan mekanik penekan permukaan tabung cairan infus ini, manset digunakan sebagai alat penekan tabung infus. Manset dirancang untuk memberi tekanan menggunakan pompa untuk memberikan tekanan udara, sehingga manset berisi udara sehingga menggembang dan menekan permukaan tabung yang dililitkan manset.

Manset memiliki dua selang dimanasalah ssatunya berfungsi untuk memasukkan udara dan mengeluarkan udara. Perancangan mekanik yang digunakan untuk menekan infus menggunakan manset ditunjukkan pada Gambar 4.

\subsection{Perancangan Program Tampilan Pemantau Tetesan Cairan Infus Menggunakan LabVIEW}

Pada perancangan program tampilan pemantau tetesan cairan infus menggunakan LabVIEW. Metode komunikasi data serial digunakan antara mikrokontroler ATMega dan komputer dengan menggunakan RS232.

Pada program LabVIEW pengunaan Visa Resource Name digunakan untuk pemilihan COM Port yang akan diaktifkan. Pemilihan nilai baudrate disesuaikan pada mikrokontroler yang terapkan yaitu sebesar 9600. Diagram blok komponen Visa Configure Serial ditunjukkan pada Gambar 5.

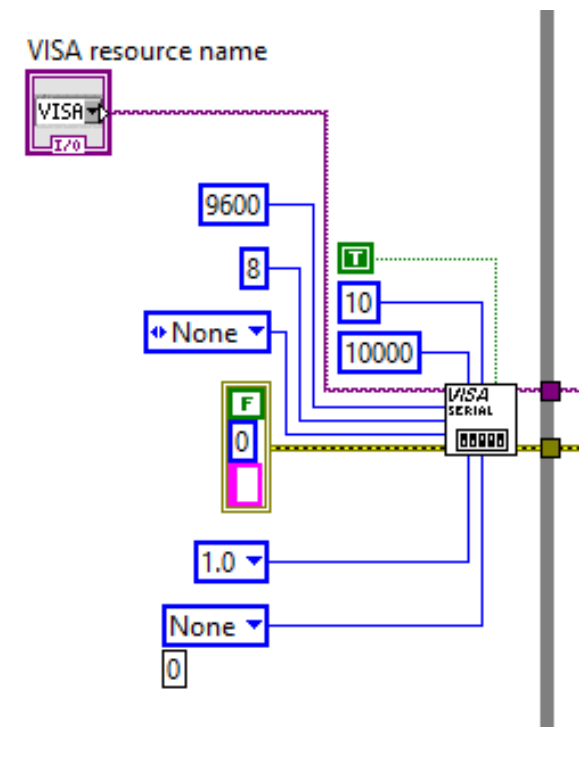

Gambar 5. Blok komponen Visa Configure Serial

Dalam proses membaca data serial digunakan komponen blok VISA Read. Data yang telah dibaca selanjutnya disimpan pada blok read buffer yang dihubungkan dalam blok while loop. Pada proses berikutnya yaitu dengan mengolahan data dan menampilkan data pembacaan. Data yang disimpan antara lain date, time, detik, setpoint, frekuensi, jumlah tetes, setpoint/f Hz, laju, status action, sudut servo, sudut stepper, motor pump dan jumlah tetes/f $\mathrm{Hz}$ dengan tipe data tersebut berupa data string. Waveform Chart berfungsi untuk memantau atau monitoring tetesan infus. Round led untuk indikator tetesan infus. Dan setpoint berfungsi untuk memasukkan nilai tetesan yang diinginkan. Diagram blok program pemantau tetesan cairan infus ditunjukkan pada Gambar 6. 


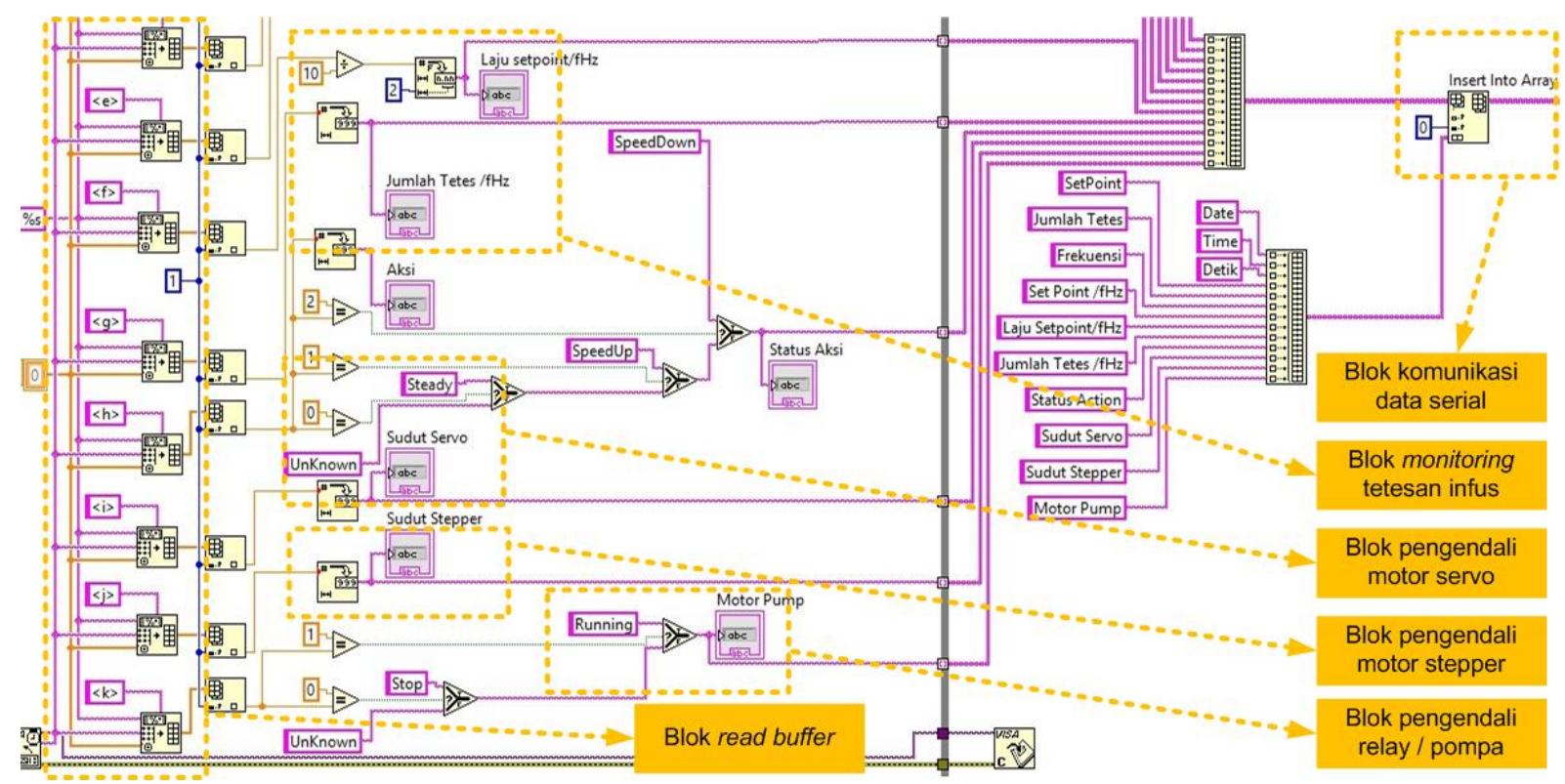

Gambar 6. Diagram blok program pemantau tetesan cairan infus

Dan tampilan sistem graphic user interface pemantau tetesan cairan infus menggunakan LabVIEW ditunjukkan pada Gambar 7.

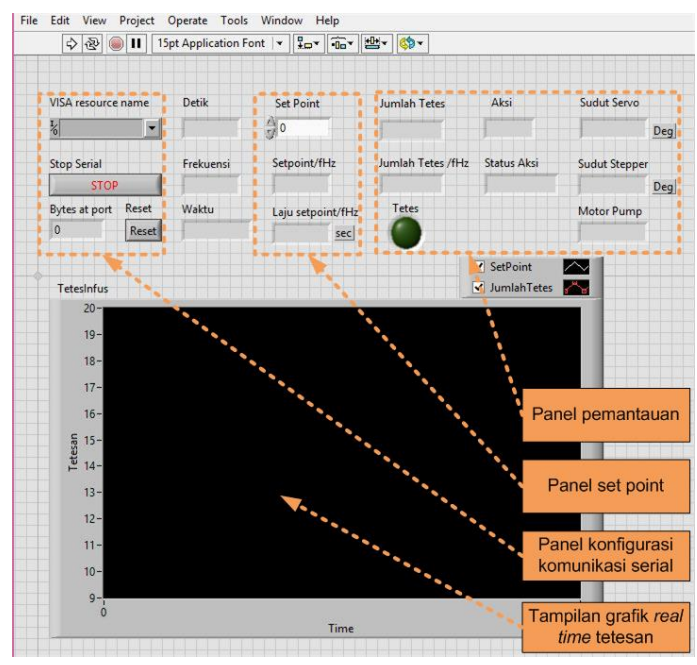

Gambar 7. Tampilan graphic user interface pemantau tetesan cairan infus

\subsection{Perancangan Kendali Pemantau Tetesan Cairan Infus Menggunakan Logika Fuzzy}

Dalam mendesain kendali logika fuzzy yang perlu diperhatikan adalah tingkah laku dari sistem infus otomatis. Hal yang harus diamati adalah pengaruh nilai data jumlah tetesan yang dideteksi oleh sensor pendeteksi tetesan cairan infus. Data masukkan fuzzy berupa data jumlah tetesan tiap menit. Untuk melakukan perhitungan pada inferensi fuzzy ditentukan terlebih dahulu data rentang nilai variabel yang digunakan antara lain kondisi relay untuk pompa, gerakan motor stepper dan motor servo. Berdasarkan rentang nilai yang didapat digunakan sebagai himpunan fuzzy berdasarkann variabel dan nilai linguistik ditunjukkan pada Tabel 1. Ketiga variabel ini untuk menentukan hasil jumlah tetesan cairan infus terhadap nilai set point jumlah tetesan yang telah ditentukan.

Tabel 1. Himpunan fuzzy

\begin{tabular}{ccc}
\hline No & Variabel & Nilai Linguistik \\
\hline 1 & relay & on \\
& & off \\
2 & motor stepper & on \\
& & off \\
3 & motor servo & on \\
& & off \\
\hline
\end{tabular}

Proses fuzzifikasi dalam logika fuzzy menggunakan masing-massing fungsi keanggotaan himpunan fuzzy dengan 3 variabel yaitu relay, motor stepper dan motor servo.

Dari fungsi keanggotaan tersebut didapatkan himpunan atau derajat keanggotaan hasil fuzzy kecepatan tetesan cairan seperti yang ditunjukkan pada Gambar 8. Masing-masing nilai keanggotaan tersebut kemudian dimasukan sebuah proses evaluation rule.

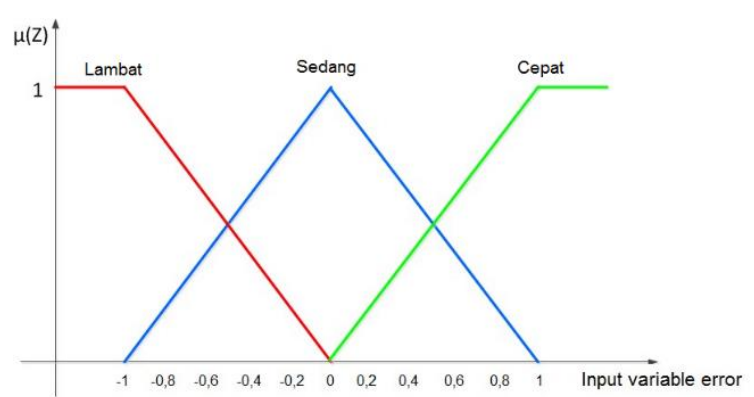

Gambar 8. Himpunan hasil fuzzy kecepatan tetesan cairan 
Fuzzy inferensi digunakan untuk menetukan nilai derajat keanggotaan dari keluaran fuzzy membentuk sebuah rules based. Dengan menggunakan operasi himpunan fuzzy rule base menggunakan aturan if-then yang diterapkan pada perangkat kendali mikrokontroler ditunjukkan pada Tabel 2.

Tabel 2. Rule Base

\begin{tabular}{ccccc}
\hline No & Relay & $\begin{array}{c}\text { Motor } \\
\text { Stepper }\end{array}$ & $\begin{array}{c}\text { Motor } \\
\text { servo }\end{array}$ & Keputusan \\
\hline 1 & off & off & off & cepat \\
2 & off & off & on & sedang \\
3 & off & on & off & cepat \\
4 & off & on & on & cepat \\
5 & on & off & off & lambat \\
6 & on & off & on & sedang \\
7 & on & on & off & lambat \\
8 & on & on & on & cepat \\
\hline
\end{tabular}

Proses defuzzifikasi dimana mencari nilai keluaran berupa nilai crisp (Z) menggunakan model Sugeno dengan posisi singelton pada sumbu $\mathrm{Z}$ seperti yang ditunjukkan pada Persamaan (2) yang untuk mengatur tetesan cairan infus.

\section{HASIL DAN PEMBAHASAN}

\subsection{Pengujian Rangkaian Sensor Tetesan Cairan Infus Menggunakan Optocoupler}

Pengujian ini bertujuan untuk mengetahui perbedaan nilai tegangan antara ada dan tidak ada halangan cahaya ke optocoupler yang merepresentasikan adanya tetesan cairan yang melalui drip chamber pada rangkaian sensor tetesan cairan infus. Hasil pengujian rangkaian sensor tetesan cairan infus menggunakan optocoupler ditunjukkan pada Tabel 3.

Tabel 3. Hasil pengujian rangkaian sensor tetesan cairan infus menggunakan optocoupler

\begin{tabular}{ccc}
\hline No & $\begin{array}{c}\text { Tegangan Tidak } \\
\text { Kondisi Terhalang } \\
\text { (volt) }\end{array}$ & $\begin{array}{c}\text { Tegangan Kondisi } \\
\text { Terhalang } \\
\text { (volt) }\end{array}$ \\
\hline 1 & 0,11 & 4,81 \\
2 & 0,13 & 4,81 \\
3 & 0,11 & 4,63 \\
4 & 0,11 & 4,63 \\
5 & 0,10 & 4,64 \\
6 & 0,11 & 4,64 \\
7 & 0,12 & 4,64 \\
8 & 0.13 & 4,63 \\
9 & 0,13 & 4,58 \\
10 & 0,11 & 4,66 \\
\hline Rata- & 0,114 & 4,667 \\
rata & &
\end{tabular}

Dari hasil pengujian dapat dilihat perbedaan tegangan antara nilai sensor antara ada halangan dihasilkan antara 0,10 - 0,13 volt dan tidak ada halangan cahaya 4,58 - 4,81 volt di optocoupler. Hasil tersebut menunjukkan bahwa rangkaian sensor tetesan memiliki kinerja yang baik sebagai pendeteksi tetesan cairan.

\subsection{Pengujian Motor Stepper Penekan Selang Mesin Pompa}

Pengujian motor stepper penekan selang mesin pompa bertujuan untuk mengetahui kestabilan tegangan pada motor stepper ketika berputar searah dan berlawanan arah jarum jam yang digunakan untuk menekan selang pompa apabila mesin pompa dalam keadaan tidak aktif untuk mencegah udara tekan tidak keluar dari manset seperti pada Tabel 5. Dari hasil pengujian menunjukkan nilai tegangan pada saat motor stepper dalam putaran berputar berlawanan atau searah jarum jam didapatkan nilai yang stabil sehingga alat penekan selang mesin pompa dapat berjalan dengan optimal.

Tabel 5 Hasil Pengujian motor stepper penekan selang

\begin{tabular}{ccc}
\hline No & $\begin{array}{c}\text { Tegangan Motor } \\
\text { Putaran Searah } \\
\text { Jarum Jam } \\
\text { (volt) }\end{array}$ & $\begin{array}{c}\text { Tegangan Motor } \\
\text { Putaran Berlawanan } \\
\text { Arah Jarum Jam } \\
\text { (volt) }\end{array}$ \\
\hline 1 & 11,12 & 10,90 \\
2 & 11,14 & 11,10 \\
3 & 11,12 & 10,90 \\
4 & 11,13 & 11,11 \\
5 & 11,15 & 10,90 \\
\hline Rata- & 11,132 & 10,982 \\
rata &
\end{tabular}

\subsection{Pengujian Motor Servo Penekan Selang Laju Cairan Infus}

Pengujian sudut servo digunakan untuk mengetahui seberapa besar sudut yang digunakan untuk menutup selang infus agar tidak terjadi tetesan sehingga dapat digunakan. Hasil pengujian motor servo penekan selang laju cairan Infus ditunjukkan pada Tabel 6. Dapat dilihat bahwa saat kondisi sudut motor $0^{\circ}$ selang infus tertutup sempurna sehingga tidak ada laju cairan infus dan saat kondisi $60^{\circ}$ selang infus terbuka menyebabkan laju cairan infus lancar.

Tabel 6 Hasil motor servo penekan selang laju cairan infus

\begin{tabular}{ccc}
\hline No & $\begin{array}{c}\text { Sudut Motor Servo } \\
\text { (derajat) }\end{array}$ & $\begin{array}{c}\text { Kondisi Laju } \\
\text { Cairan Infus }\end{array}$ \\
\hline 1 & 0 & Terhenti \\
2 & 5 & Melaju lambat \\
3 & 30 & Melaju lancar \\
4 & 50 & Melaju lancar \\
5 & 60 & Melaju lancar \\
\hline
\end{tabular}




\subsection{Pengujian Kinerja Sistem Pemantauan Tetesan Cairan Infus Mengunakan Fuzzy}

Pengujian ini bertujuan untuk mengetahui kinerja sistem pemantauan tetesan cairan infus otomatis yang diterapkan menggunakan logika fuzzy. Prosedur pengujian kinerja sistem dilakuakn sebanyak 15 kali. Nilai tetesan setiap menit hasil percobaan dibandingkan dengan nilai set point yang dimasukkan. Dari Tabel 7. untuk menguji kinerja sistem pemantauan tetesan cairan infus otomatis dengan menggunakan kendali logika fuzzy dengan nilai set point 20 tetes dalam waktu 1 menit, diperoleh persentase keberhasilan sebesar 96,75\%. Sehingga dapat disimpulkan bahwa sistem ini memiliki kinerja yang baik dengan menerapkan logika fuzzy.

Tabel 7 Hasil pengujian kinerja sistem pemantauan tetesan cairan infus otomatis dengan menggunkan logika fuzzy

\begin{tabular}{|c|c|c|c|}
\hline No & $\begin{array}{c}\text { Nilai Set Point } \\
\text { Tetesan } \\
\text { (Tetes/menit) }\end{array}$ & $\begin{array}{c}\text { Nilai Tetesan } \\
\text { Terukur } \\
\text { (Tetes/menit) }\end{array}$ & $\begin{array}{c}\text { Prosentase } \\
\text { Keberasila } \\
(\%)\end{array}$ \\
\hline 1 & 20 & 20 & 100 \\
\hline 2 & 20 & 20 & 100 \\
\hline 3 & 20 & 20 & 100 \\
\hline 4 & 20 & 18 & 88,9 \\
\hline 5 & 20 & 20 & 100 \\
\hline 6 & 20 & 20 & 95,24 \\
\hline 7 & 20 & 21 & 97,74 \\
\hline 8 & 20 & 20 & 100 \\
\hline 9 & 20 & 20 & 100 \\
\hline 10 & 20 & 20 & 100 \\
\hline 11 & 20 & 21 & 95,24 \\
\hline 12 & 20 & 20 & 100 \\
\hline 13 & 20 & 29 & 94,74 \\
\hline 14 & 20 & 17 & 82,36 \\
\hline 15 & 20 & 20 & 100 \\
\hline \multicolumn{3}{|c|}{ Rata-rata persentasi keberasilan } & 96,75 \\
\hline
\end{tabular}

\section{KESIMPULAN}

Setelah melakukan perancangan, pengujian dan analisa data hasil dari pengujian, maka dapat disimpulkan perancangan rangkaian tetesan cairan infus menggunakan optocoupler dapat digunakan pendeteksi tetesan cairan yang melalui drip chamber. Kinerja dari sistem pemantauan aliran cairan infus secara otomatis dengan menggunaka logika fuzzy yang telah diuji memiliki tingkat keberhasilan $96,75 \%$ dengan nilai set point 20 tetes dalam waktu 1 menit. Sebagai pengembangan lebih lanjut perlu dilakukan untuk mendapatkan sistem yang lebih akurat. Diantaranya adalah dalam menggunakan optocoupler dengan peletekan yang presisi agar bekerja optimal dalam pembacaan tetesan infus di berbagai kondisi dan lokasi pengujian. Dan sistem kendali dapat dikembangkan menjadi jaringan syaraf tiruan agar sistem bisa melakukan proses lebih cepat dengan akurasi yang lebih tinggi.

\section{DAFTAR PUSTAKA}

FAHMIZAL, S., GALIH, ARROFIQ, M. and Mayub, A., 2017. Logika Fuzzy Pada Robot Inverted Pendulum Beroda Dua, Jurnal Teknologi Informasi dan Ilmu Komputer (JTIIK), vol. 4, no. 4, p. 244, Des. 2017 [Online].

Available: http://jtiik.ub.ac.id/index.php/jtiik/article/vi ew/484. [Accessed: 06-April-2018]

MULJODIPO, N., SOMPIE, S.R. and ROBOT, R.F., (2015). Rancang Bangun Otomatis Sistem Infus Pasien. E-Journal Teknik Elektro Dan Komputer, 4(4), pp.12-22.

NATALIANA, D., TARYANA, N. and RIANDITA, E.G.I., 2016. Alat Monitoring Infus Set pada Pasien Rawat Inap Berbasis Mikrokontroler ATmega 8535. ELKOMIKA: Jurnal Teknik Energi Elektrik, Teknik Telekomunikasi, \& Teknik Elektronika, 4(1), p.1.

PRIMAHAYU R. A., UTAMININGRUM, F., and SYAUQY, D., 2017. Sistem Monitoring Cairan Infus Terpusat Menggunakan Pengolahan Citra Digital. Jurnal Pengembangan Teknologi Informasi dan Ilmu Komputer, 1(8), pp. 649-657.

RISKITASARI, S., HAMIDA, F., NURWICAKSANA, W.A., ADITYA, M.R. and ADHISUWIGNJO, S., 2016. SIMOCI (Sistem Monitoring Cairan Intravena) Di Ruang Icu Menggunakan Zigbee. Prosiding SNST Fakultas Teknik, 1(1).

SETIAWAN, D. and FARAH, M., 2017. Rancang Bangun Alat Pengatur Dan Monitoring Jumlah Tetesan Infus Berbasis Labview (Undergraduate Thesis, Universitas Airlangga).

WADIANTO, W. and FIHAYAH, Z., 2016. Simulasi Sensor Tetesan Cairan, Pada Infus Konvensional. Jurnal Kesehatan, 7(3), pp.394-401.

YUNARDI, R. T. and MARDIYANTO, R., 2017. Perancangan Sistem Kendali pada Lengan Assistive Social Robot menggunakan Kamera. Jurnal Nasional Teknik Elektro, vol. 6, no. 2, 2017 [Online]. Available: http://jnte.ft.unand.ac.id/index.php/jnte/arti cle/view/402. [Accessed: 17-September2017]

ZAINURI, A., SANTOSO, D.R. and MUSLIM, M.A., 2012. Monitoring dan Identifikasi Gangguan Infus Menggunakan Mikrokontroler AVR. Jurnal EECCIS, 6(1), pp.49-54. 
Halaman ini sengaja dikosongkan 